九州大学学術情報リポジトリ

Kyushu University Institutional Repository

\title{
Depositional and Tectcmic Settings of Cherts around the Akiyoshi Limestone Group, Southwest Japan
}

Uchiyama, Takanor i

G. M. Dept., Nippon Schlullberger Co. Ltd.

Sano, Hiroyoshi

Faculty of Sciences, Kyushu University

Kanmera, Kametoshi

Faculty of Sciences, Kyushu University

https://doi.org/10.5109/1526113

出版情報：九州大學理學部紀要：Series D, Geology. 26 (1)，pp.51-68，1986-01-20. Faculty of Science, Kyushu University バージョン：

権利関係 : 
Mem. Fac. Sci., Kyushu Univ., Ser. D, Geol., Vol. XXVI, No. 1, pp. 51-68, text-figs. $1-9$, table 1 , plates $6-8$, January 20,1986

\title{
Depositional and Tectonic Settings of Cherts around the Akiyoshi Limestone Group, Southwest Japan
}

\author{
Takanori UCHIYAMA*, Hiroyoshi SANO, and \\ Kametoshi KANMERA
}

\begin{abstract}
For the purpose of understanding depositional and tectonic settings of cherts around the Akiyoshi Limestone Group (Visean to Guadalupian), Southwest Japan, this paper documents their distribution, relationships to other rock units, stratigraphy, petrography, and age. The cherts occur as slabs and blocks of varied sizes and forms, and are complexly juxtaposed with and enclosed in pervasively sheared mudstones and sandstones. Geological and paleontological evidence suggests that the terrigenous clastic rocks are of late Guadalupian to probably post-Guadalupian age. The cherts and associated rocks exhibit the following stratigraphic sequence: (1) lower part $(20 \mathrm{~m}$ thick) composed mainly of reddish volcaniclastic rocks with thin chert interbeds in the upper part. (2) upper part (up to $100 \mathrm{~m}$ ) consisting of bedded or massive cherts. The cherts are characterized by a copious amount of siliceous sponge spicules and by admixture of volcanic detritus in varying degrees, particularly in the lower part.

The radiolarian dating indicates that the major part of the cherts ranges in age from Wolfcampian to Guadalupian. At several levels of the volcaniclastic rocks-chert sequences there occur limestone lenses with siliceous limestone envelopes which have resulted from mixing in the unconsolidated state of sponge spicule-rich sediments and calcitic skeletal debris exogenetically derived from the Akiyoshi carbonate buildup of shallow-water origin. Those of the lowest part yield fusulinaceans of Visean age, thereby the volcaniclastics-chert sequence is deduced to be coeval with the almost whole sequence of the Akiyoshi Limestone Group.

All lines of evidence indicate that the cherts accumulated on the lower flank and foot of a volcanic seamount capped by a reef complex, the Akiyoshi Limestone Group, and on the surrounding ocean floor. These rocks formed in a realm far removed from influx of terrigenous detritus.

Based on lithologic affiliation and age, rocks of the area are grouped into two major tectonostratigraphic units of completely different lithology; the one composed of rocks of oceanic setting including a greenstone-reef limestone complex and coeval deep-water sediments represented by the spicular cherts, both ranging in age from Visean to Guadalupian, and the other consisting of terrigenous clastic rocks of late to post-Guadalupian age. Complex juxtaposition of these two units is interpreted most likely as the result of collisional accretion of a seamount accompanied by a reef complex and spicular cherts toward terrigenous clastic rocks that accumulated within a trench. Accretionary process of these rocks probably took place during Late Permian to Early Triassic times.
\end{abstract}

* G. M. Dept., Nippon Schlunberger Co. Ltd., Sagamihara, Kanagawa, 229 Japan. Manuscript received August 15, 1985. 


\section{Introduction}

This paper describes results on geological, sedimentological, and paleontological examinations of cherts adjacent to the Akiyoshi Limestone Group in Yamaguchi Prefecture, Southwest Japan, and interpretes their depositional setting. Also tectonic setting of the chers is presented, because they play an important role in the tectonic evolution of the Inner Zone of Souhwest Japan.

Since the first paleontological description by OzAWA (1923), the Akiyoshi Limestone Group has been celebrated mainly for Early Carboniferous (Visean) to late Middle Permian (Guadalupian) fusulinacean biostratigraphy (OzAWA, 1925; TORIYAMA, 1958; MURATA, 1961; OTA, 1977 and others). Sedimentological studies of the limestone have also been made, focusing upon reconstruction of its depositional environment (Ето, 1967; OTA, 1968; NAGAI, 1978; НASHIмото, 1979 and others). The group comprises basic volcanic and volcaniclastic rocks and an overlying thick pile of limestones, the latter being $650 \mathrm{~m}$ thick (OTA, 1977). It has been generally interpreted as a geosynclinal organic reef complex originated from the submarine volcanic activity.

Around the Akiyoshi Limestone Group, "non-calcareous Paleozoic" rocks widely occur. They consists principally of cherts, sandstones, and mudstones, and include some small bodies of basic volcaniclastic rocks and limestones. Many workers have examined stratigraphy, paleontology, and geologic structure of these rocks (TORIYAMA, 1954; MURATA, 1961; KAWAI, 1963; KAWANo et al., 1963; OTA, 1968; Fujil and Mikami, 1970; FuJiI, 1972; Mikami, 1974). The conclusion by these previous workers except KAWAI (1963) is summarized as follows; (1) The cherts, a few tens to a few hundreds meters thick, depositionally alternate with sandstones and mudstones, and display lateral lithologic changes into terrigenous clastic rocks. In other words, the cherts occur at several stratigraphic levels, being intercalated within and interfingered with the terrigenous clastic rocks. (2) Age of the noncalcareous rocks ranges from Early Carboniferous to late Middle Permian, being coeval with the Akiyoshi Limestone Group. This designation has been based mainly on fusulinaceans from limestone conglomerates in the mudstones and cherts. Thus, the Akiyoshi Limestone Group including greenstones is interpreted as having been underlain by and also laterally changed into the terrigenous clastic rocks which contain cherts, as diagrammatically illustrated by OTA (1968). On the other hand, KAWAI (1963) mapped the cherts to have overthrust onto the terrigenous clastic rocks, and suggested that the cherts are coeval with the Akiyoshi Limestone Group.

The previous interpretation raises questions particularly as to the depositional setting of the cherts and the contemporaneity of the non-calcareous Paleozoic rocks with the Akiyoshi Limestone Group. These questions have come from uncertainties in the precise age of the cherts and terrigenous clastic rocks and their field relationships.

Based on investigations mainly in the northern and western parts of the Akiyoshi district, KANMERA and NISHI (1983) and KANMERA (1983) gave a new interpretation to the relationships among the Akiyoshi Limestone Group, the cherts, and the terrigenous clastic rocks. They assigned the Akiyoshi Limestone 
Group to a reef complex resting upon an isolated, oceanic volcanic seamount pedestal, the cherts to the coeval pelagic sediments accumulated on the flanks of the volcanic seamount and on the surrounding oceanic floor, and the terrigenous clastic rocks to the trench-fill sediments. The complex juxtaposition of these different kinds of rocks was explained by accretion tectonics. However, no fossils have been found from the cherts and terrigenous clastic rocks.

In this paper, we summarize the distribution, lithology, and structure of the non-calcareous Paleozoic rocks, detail the field relationships of the cherts and adjoining terrigenous clastic rocks, and describe lithostratigraphy, microscopy, and age of the cherts. The age of the cherts was newly confirmed by radiolarian fossils.

\section{Geologic Framework}

Rocks studied are lying south and southeast of the Akiyoshi Limestone Plateau (Fig. 1). Four geologic groups are recognized in the mapped area
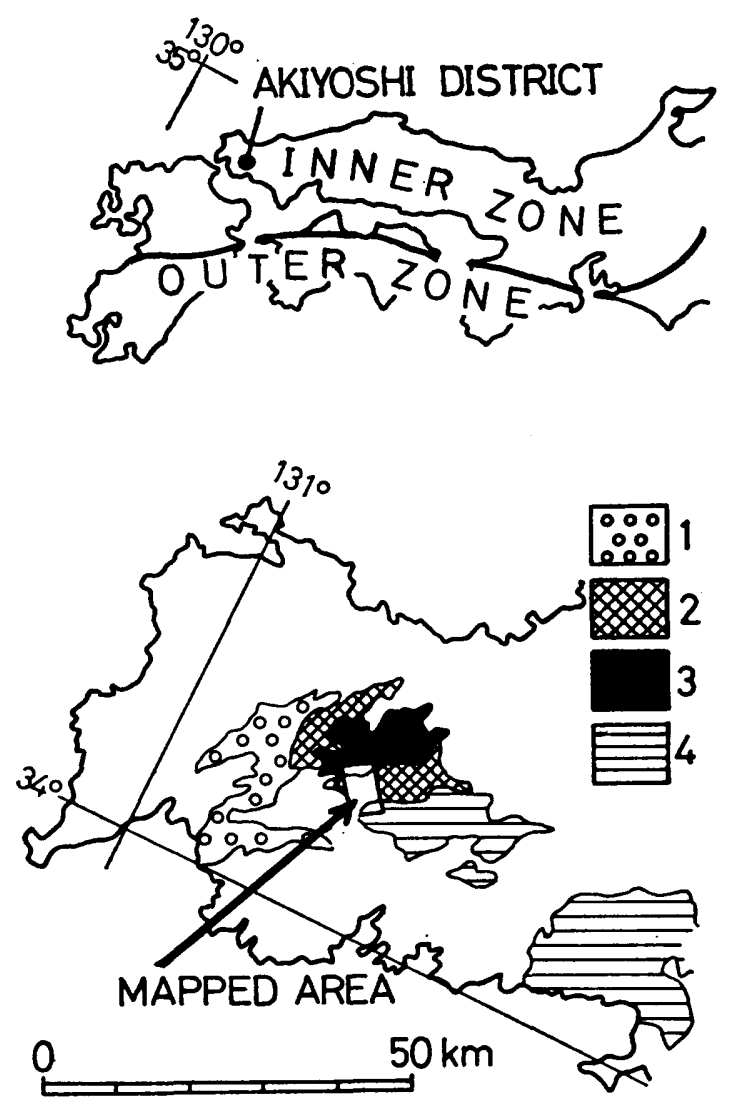

Fig. 1. Maps showing the location of the Akiyoshi district (above), and illustrating the approximate distribution of pre-Jurassic rocks around the mapped area (below). 1. Late Triassic clastic rocks of molasse facies; 2. non-calcareous Paleozoic rocks; 3. Akiyoshi Limestone Group; 4. Sangun metamorphic rocks. 
(Fig. 2) ; Akiyoshi Limestone Group, non-calcareous Paleozoic rocks, Sangun metamorphic rocks, and Late Cretaceous volcanic rocks. Except the last one, these groups trend ENE-SWS, have a distinct lithologic assemblage respectively, and are separated by faults from one another. Summary of lithologic characteristics of the former two groups is as follows: The Akiyoshi Limestone
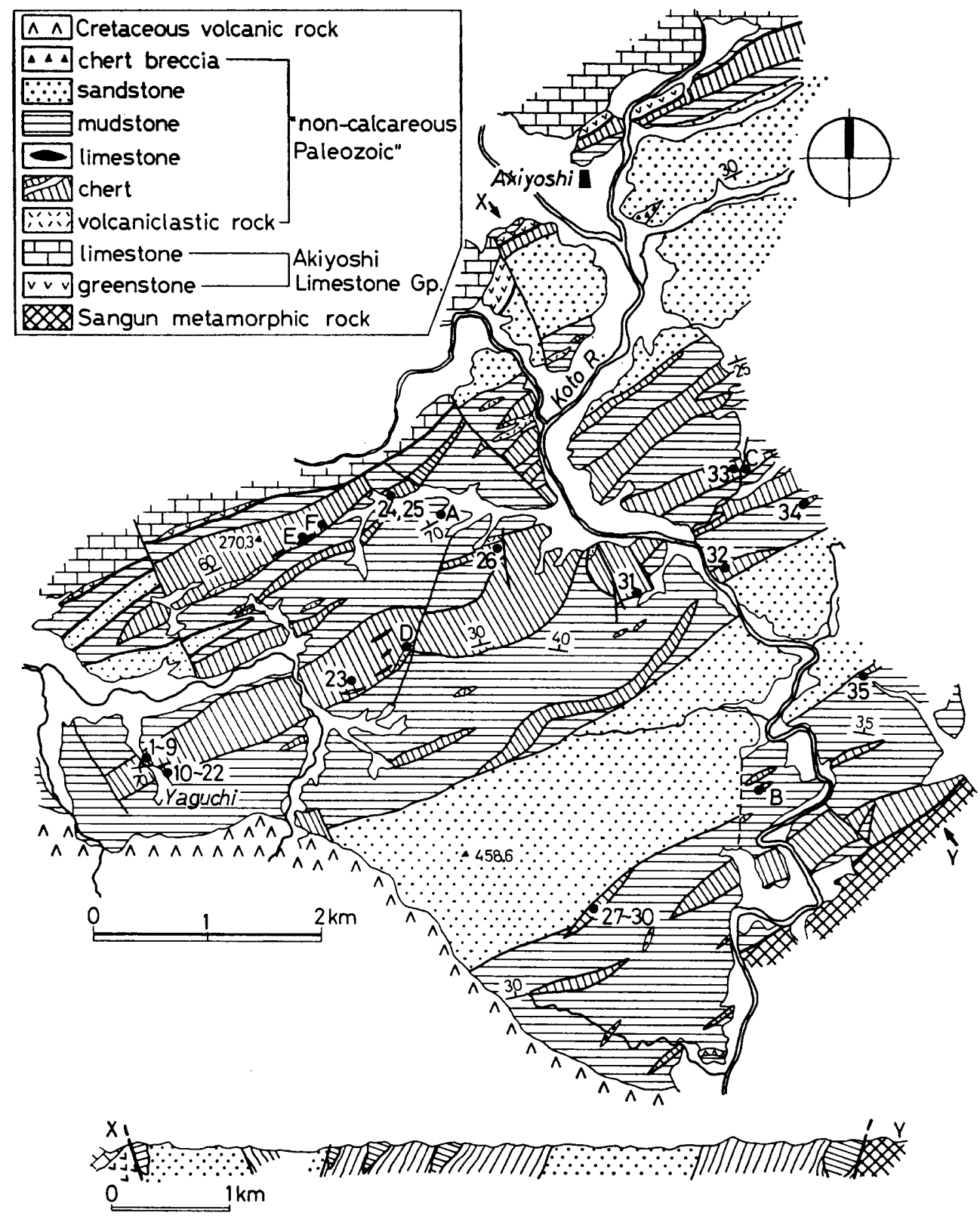

Fig. 2. Geological outline map and generalized geologic profile of the Akiyoshi district. 
Group, lying along the northern margin of the area, comprises greenstones and a conformably overlying thick sequence of limestone. The greenstones include basalt flow rocks, occasionally pillowed and remarkably vesiculated, and volcaniclastic rocks. The limestone consists of white to light-grey bioclastic limestone with reefal biolithite lenses at many levels in the lower part (OTA, 1968, 1977; NAGAI, 1978 and others). The limestones exposed in the area belong chiefly to Early Carboniferous in age. The non-calcareous Paleozoic rocks include, in order of abundance, mustones, sandstones, and cherts, being accompanied by a small amount of basic volcaniclastic rocks, limestones, and pebbly mudstones. These rocks in the area have been called Ota Group (ToRIYAMA, 1954; MURATA, 1961; KAWANo et al., 1963) or Ota Formation (FUJII, 1972). Our present investigations, however, revealed that these rocks are not of a conformable sequence, but of sediments originally accumulated in different basins respectively and of geologic bodies subsequently juxtaposed and in part chaotically mixed with one another by accretion tectonics, as described below. Therefore the overall revision of the stratigraphy previously established is required.

To the west, out of the mapped area, these juxtaposed non-calcareous Paleozoic rocks are known to be unconformably covered by the Late Triassic clastic rocks of molasse facies.

\section{General Aspects of Non-calcareous Paleozoic Rocks}

Mudstones are most dominant among the non-calcareous Paleozoic rocks in the area. They are dark-grey, sandy to silty, and commonly include thin beds of sandstone, usually 3 to $5 \mathrm{~cm}$ thick. Grading and parallel laminations are rarely found in the sandstone beds. In places, layers of pebbly mudstone, up to $5 \mathrm{~m}$ thick, occur in the mudstones. The pebbly mudstone contains rounded pebbles and cobbles of chert and acidic igneous rocks and angular clasts of siliceous marl in an argillaceous matrix. The mudstones are pervasively sheared and intensely contorted (Pl. 6, Figs. 1, 2). The thin sandstone interbeds are usually disrupted, having resulted in structural lenses and blocks, and often display northwesterly dipping asymmetrical folds (Pl. 6, Fig. 1).

Large slabs of sandstone as thick as up to 700 to $800 \mathrm{~m}$ are enveloped in sheared mudstones in the northern and southern parts of the area (Fig. 2), while much smaller lenses and blocks, less than several meters across, are dispersed throughout the area. The sandstones are largely massive or thickbedded, and contain rare mudstone interbeds. They are medium- to coarsegrained, and rarely have crude parallel laminations. Laterally discrete, intraformational layers condensed with chert breccias are found in the massive sandstones at a few places.

The cherts also occur as slabs or blocks of various sizes and forms. Large slabs lie in the central part of the area (Fig. 2), and disrupted, small blocks are scattered throughout the area and tend to be abundant locally. These blocks consist almost exclusively of bedded and massive cherts, but large slabs are closely associated with volcaniclastic rocks and limestones. The cherts, volcaniclastic rocks, and limestones represent a distinct lithologic assemblage, and 


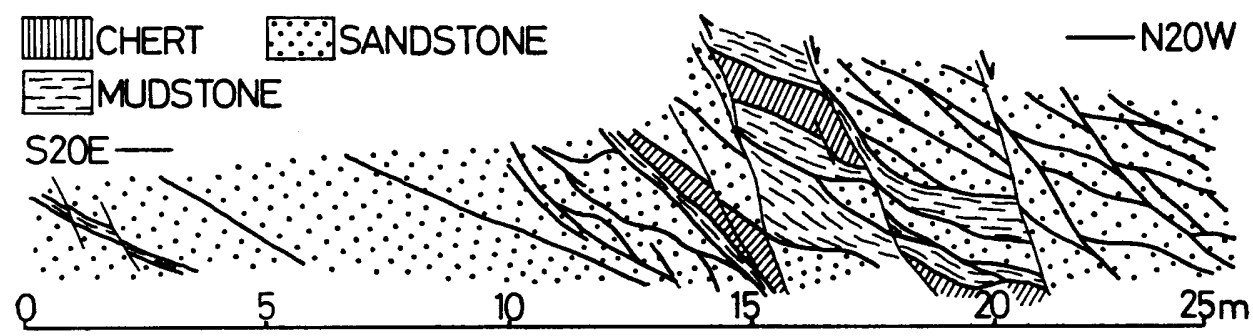

Fig. 3. Intensely sliced and faulted chert blocks and surrounding terrigenous clastic rocks. Note that the low-angled, imbricated structure is cut by high-angled faults. Locality is shown as B in Fig. 2.

form a lithostratigraphic unit, as described in the following section. No terrigenous rocks are intercalated within the chert blocks and slabs. The cherts are intensely contorted, and often display folds similar in form to those of thin sandstone beds in the mudstones (Pl. 6, Fig. 3).

All of the non-calcareous Paleozoic rocks are exposed repeatedly by strike faults, thereby forming an imbricated structure steeply dipping generally to the northwest (Fig. 2). Noteworthy is that relatively low-angled thrust faults are truncated by more steeply inclined faults (Fig. 3). This means that the low-angled thrust faults are primary, and essential to the overall geologic structure of the non-calcareous Paleozoic rocks, although considerably modified by the high-angled faults.

\section{Description of Cherts}

A. Field relationship between cherts and terrigenous rocks

The mode of occurrence of cherts is divisible into the following two types:

(1) extensive to mappable-scale large slabs with marked lateral continuity and consisting of folded or imbricated beds; (2) laterally discrete small blocks measuring on exposures less than $10 \mathrm{~m}$ in length and breadth. In both cases no lithologic gradation can be recognized at all between the cherts and surrounding terrigenous clastic rocks.

The chert bodies of the former type are bounded by adjoining mudstones and sandstones with a distinct thrust or a high-angled fault in most cases. The high-angled fault is probably related to subsequent tectonic disturbance, because it often cut the low-angled thrust, as described before. However, the southern boundary of the Hiranoyama slab, one of the largest chert slabs lying in the central part of the area, is worthy to note, where the volcaniclastic rocks underlying cherts are bounded on the south by mudstones which are much less sheared than the argillaceous rocks in the area. The juncture between both rocks is not marked by a throughgoing thrust or fault, but is represented by a weak shear surface. The mudstones in the immediate vicinity contains a few detached, irregular-shaped masses of volcaniclastic rocks less than a few meters across. These features would be expected to have resulted from gravitational submarine sliding of the Hiranoyama slab. 
The chert bodies of the latter type are surrounded by highly sheared mudstones with a distinct shear surface contact in many cases (Fig. 3). However, unsheared contact was also recognized at several sites. It is represented by a sharp, but uneven or irregularly rugged surface. The bedding structure of the chert blocks is more or less oblique to and transected by the contact surface. These structures show neither conformable nor tectonic boundary. The adjoining mudstones contain blocks of sandstone and volcaniclastic rocks. On the basis of these observations we believe that the small-scale chert blocks have been primarily gravitational allochthonous masses, although the original relationship has presently been largely modified by subsequent tectonic disturbance.

\section{B. Lithostratigraphy of cherts}

In the mapped area, there is no single slab or block within which a complete sequence of cherts and associated rocks can be measured. However, some large slabs in the central and northern parts of the area retain orderly sequences capable of piecing out, thereby a nearly complete stratigraphy (Fig. 4) can be reconstructed.

The sequence begins with a 20 -m-thick volcaniclastic rock (Figs. 4, 5), which includes claystone, siltstone, and granule conglomerate of varying thick-

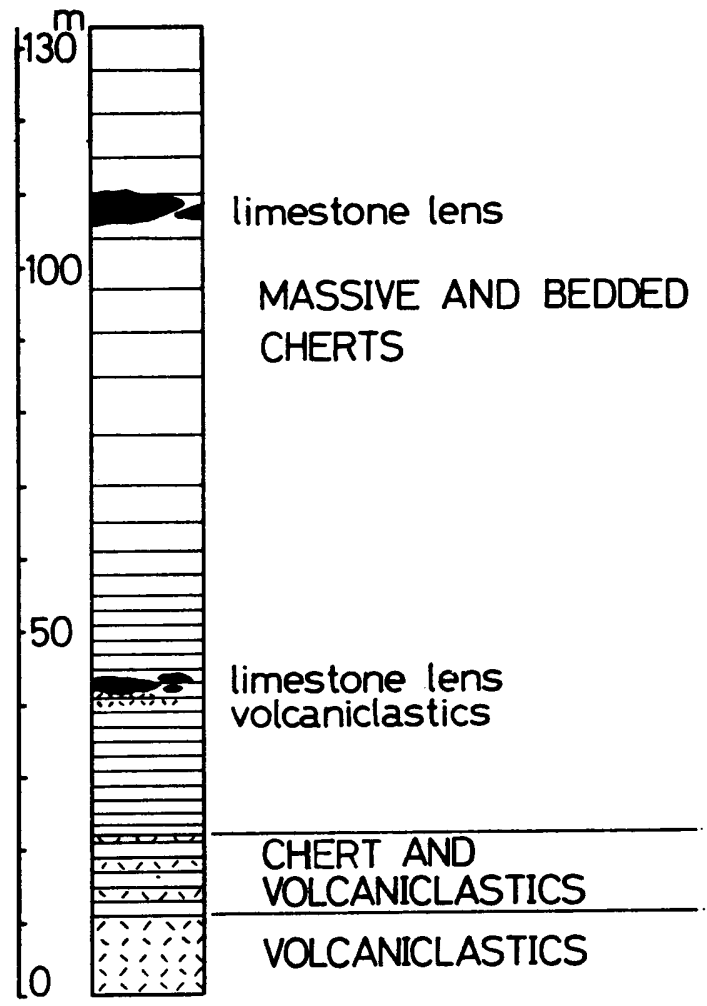

Fig. 4. A composite columnar section illustrating the stratigraphic sequence of volcaniclastic rocks, cherts, and limestone lenses, pieced together from fault-bounded outcrops. 


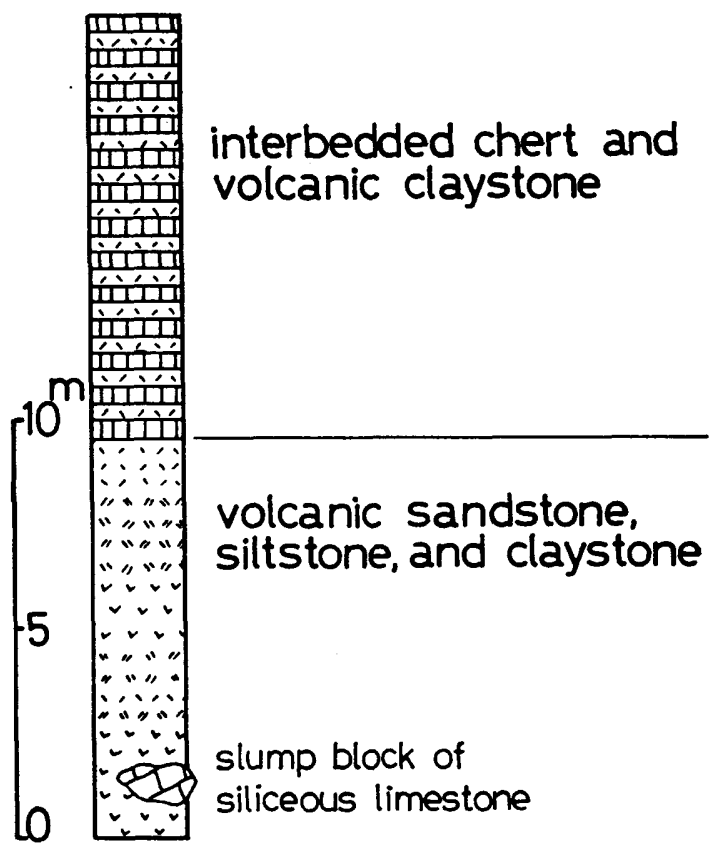

Fig. 5. A measured section showing the stratigraphic details of the basal part of the volcaniclastics-chert sequence. Measured at loc. D in Fig. 2.

ness. The volcanic sandstone and conglomerate are dominant in the lower part of the sequence, while the volcanic claystone and fine-graind siltstone dominate in the upper part. Thus, this volcaniclastic member shows a finingupward sequence. The volcaniclastic rocks are typically reddish to brownishred, and occasionally dark-green. The volcanic sandstones and siltstones exhibit internal sedimentary structures indicative of redeposition; parallel, graded, and cross-laminations and scour structures are observed. Slump beds of siliceous micrite up to a few meters thick are present in the lower part of the sequence (Fig. 5). Intercalated in the upper part are beds of chert highly contaminated with volcanic detritus (Fig. 5). These chert beds are commonly less than $10 \mathrm{~cm}$ thick, and gradually increase up section in number and thickness. Thus, the sequence changes into interbeds of chert and clayey volcaniclastic rock.

The volcaniclastic unit is succeeded by a thick sequence of chert, that reaches in thickness $100 \mathrm{~m}$ in places, typically 70 to $80 \mathrm{~m}$ (Fig. 4). It comprises bedded and massive cherts with a small amount of limestones and volcaniclastic rocks. Thin-bedded cherts (Pl. 6, Fig. 2) are dominant in the lower part, while the upper part is dominated by massive to thick-bedded chert. The chert is commonly greyish-green to blueish-green, occasionally grey to dark-grey. Although they show a considerable variety in megascopic features, they are hard, dense, and have subvitreous lusters. Their fresh rocks break with conchoidal and smooth surfaces. They contain rare parallel laminations condensed with volcanic detritus. The thin-bedded cherts are often interbedded with films 


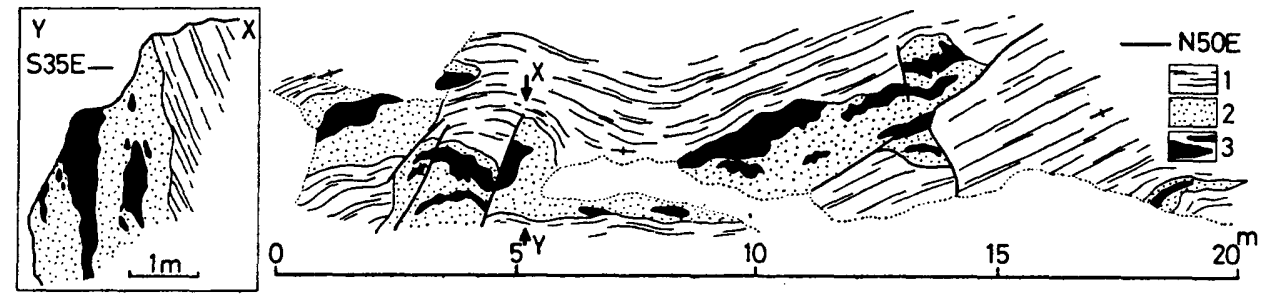

Fig. 6. Limestone lenses embedded within spicular cherts. 1. spicular chert; 2. siliceous limestone; 3 . bioclastic limestone and calclithite. Loc. $\mathbf{E}$ in Fig. 2.

or thin layers of siliceous claystone. Top and bottom bedding surfaces of chert beds are distinct, but irregularly undulated and sometimes knobby.

The limestones occur as lenses or irregular-shaped pods at a few stratigraphic levels in the chert sequence (Fig. 4). They range in thickness from a few centimeters to a few tens of meters, and rapidly thicken and thin out (Fig. 6). Their longer axis tend to be oriented nearly parallel with bedding surfaces of the surrounding cherts. They are composed of light-grey massive limestone and siliceous limestone. Noteworthy is that the siliceous limestone occurs enveloping or underlying the light-grey limestone (Fig. 6). The contact between the limestone lenses and cherts are distinct, but are uneven. The mode of occurrence of the limestones and siliceous limestones is the same as that described by KANMERA and NISHI (1983) and KANMERA (1983) from the area north and northwest of the Akiyoshi Limestone Plateau.

It should be restated that despite detailed field observations and thin-section examinations neither beds nor laminae of terrigenous materials have been found within the sequence of the cherts and volcaniclastic rocks.

\section{Microscopic description of chert and accompanied limestone \\ C-1. Chert}

Chert of the area is characterized by a copious amount of siliceous sponge spicules (Pl. 7, Figs. 1, 2), as named siliceous spiculite by FUJII (1972), and is accompanied by a varied amount of volcanic detritus. Both lithologic components are set in a matrix of cryptocrystalline quartz and a small amount of clay minerals. Radiolarian remains are sporadic in general or completely absent in places.

In thin-sections, siliceous sponge spicules are in many cases as much as more than $50 \%$ of the rock. They are largely of rod and needle forms with 100 to $800 \mu \mathrm{m}$ long and 20 to $300 \mu \mathrm{m}$ across (Pl. 7, Fig. 1), but considerable morphological varieties are recognized in residues treated by $\mathrm{HF}$ : triactines with rays covered by annular swellings, tetractines with pointed ends, hexactines and triactines with forked ends, and the variety of monaxones occur. Although no indication of winnowing has been recognized, differences in concentration of the spicules has resulted in rare laminae parallel with the bedding surfaces. Poor gradation in number of spicules occurs in the upper border of the spicule-rich laminae. 
The cherts of the lower part are contaminated with volcanic detritus in a greater or lesser degree. The cherts that are interbedded with volcaniclastic rocks are largely composed of a mixture of volcanic detritus and siliceous sponge spicules. Those with rhythmically interlayered siliceous claystone partings also contain some volcanic detritus, in some cases 10 to $15 \%$ of the rock. In the chert beds volcanic detritus occasionally form thin laminae. The volcanic grains are, as described by FUJII (1972), largely of feldspar and rock fragments. They are angular and varied in size, larger ones ranging from several tens to a few hundreds of microns. No distinct terrigenous grains such as rounded quartz have been found at all in the chert and associated rocks.

C-2. Limestone accompanying chert

As described before, two types of limestones, light-grey limestone and siliceous limestone, are recognized within the lenses. The majority of the former is composed mainly of fusulines, bioclasts of corals, crinoids, brachiopods, and clacareous algae, and a sparry calcite cement or lime-mud matrix; the contained fossils and microfacies are the same as those commonly found in the Akiyoshi Limestone Group. Associated with the bioclastic limestones are calclithites consisting of angular limestone lithoclasts of various lithologies. Fragments of fusulines, corals, and crinoids and small debris of spicular chert and basalt are also present. The matrix is narrow, and consists of comminuted bioclasts and lithoclasts. The siliceous limestone is characterized by a chaotic mixture of calcitic skeletal debris and siliceous sponge spicules, and is occasionally accompanied by lithic fragments of limestone and basalt (Pl. 7, Figs. 3, 4). The contained sponge spicules vary in size and amount; In the case that the spicules are dominant, they are tiny, usually less than $50 \mu \mathrm{m}$ across and $400 \mu \mathrm{m}$ long, and are set in a cloudy matrix of microcrystaline calcite and quartz, hence such a rock type is referred to as siliceous lime-mudstone or biomicrite (Pl. 7, Fig. 4). In the case that the limestone contains much abundant and larger calcitic bioclasts, the spicules are larger, attaining $300 \mu \mathrm{m}$ across and 800 to $1000 \mu \mathrm{m}$ long, and are scattered at random. This type of limestone can be assigned to sponge spicule-bearing siliceous wackestone or packstone ( $\mathrm{Pl}$. 7, Fig. 3 ). In these limestones the spicules are partly corroded or replaced by calcite, and the rocks have resulted in having a microcrystalline quartz cement in addition to a lime-mud matrix. These microscopic properties indicate that the siliceous

\section{Explanation of Plate 6}

Fig. 1. Intensely sheared mudstone with thin tectonic lenses of sandstone. Loc. A in Text-Fig. 2.

Fig. 2. Close-up of a part of Fig. 1. Note strong disruption of sandstone interbeds.

Fig. 3. Typical bedded cherts, displaying isoclinal folds, of which axes are gently inclined to the north (right side of the photograph).

Loc. 23 in Text-Fig. 2.

Fig. 4. Chert blocks with lenticular and irregular forms embedded in intensely sheared mudstones.

Loc. $\mathrm{C}$ in Text-Fig. 2. 

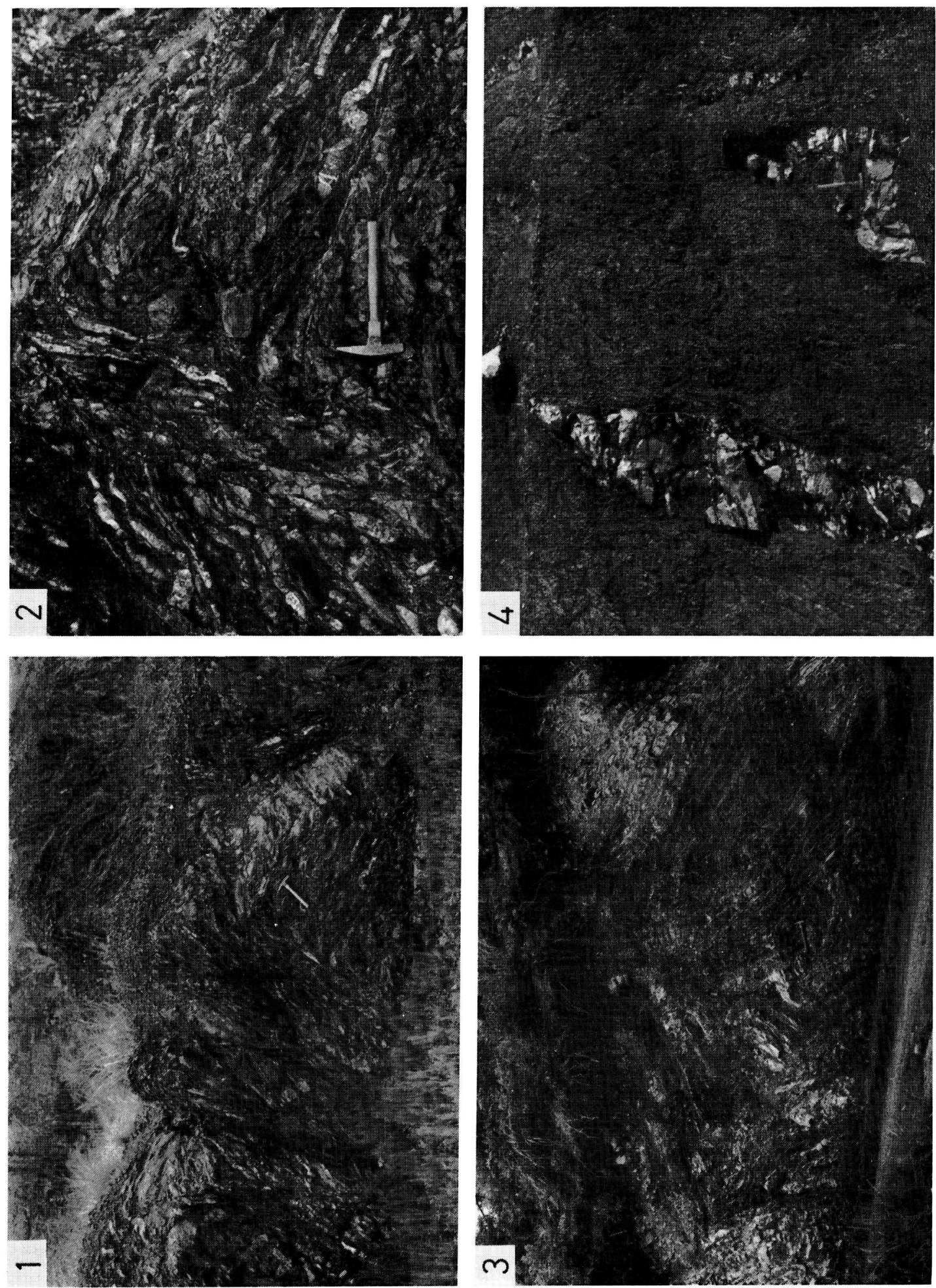

T. Uchiyama et al.: Cherts around Akiyoshi 

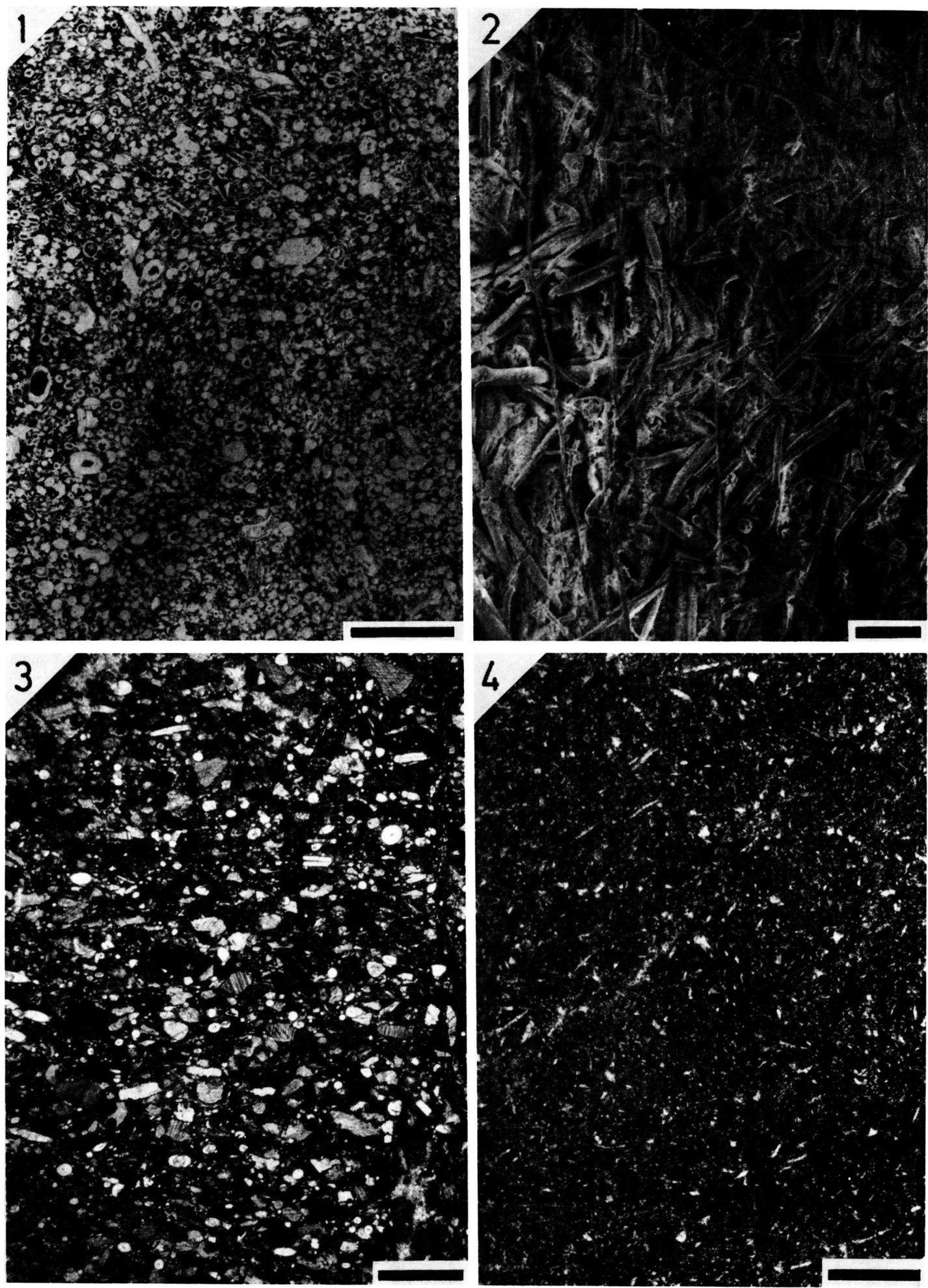

T. UChiyama et al.: Cherts around Akiyoshi 
limestone represents a mixture of calcitic bioclasts of shallow-water origin and siliceous sponge spicules. The limestone lenses and pods within cherts are interpreted as displaced bodies derived from the shallow-water environment into the depositional site of the spicular chert by sediment gravity flow, possibly debris flow. The occurrence of the mixed facies means that both the spicular chert and limestone were unconsolidated at the time of diplacement and deposition of the limestone, and therefore the limestone lenses are coeval with the cherts at the same stratigraphic level.

\section{Age of cherts}

Cherts of the area were dated newly by radiolarian fossils. Among more than 250 chert samples, 35 samples from 11 sections (Fig. 2) yielded datable radiolarians, in which 10 species of 3 genera were identified (Table 1). These radiolarian fossils indicate mid-Early Permian to late Middle Permian (late Wolfcampian to Guadalupian) in age, and can be divided into 5 assemblage zones, according to the radiolarian zonation established by IsHIGA et al. (1982a)

Table 1. List of radiolarian fossils from the cherts of the Akiyoshi district.

\begin{tabular}{|c|c|c|c|c|c|c|c|c|c|c|c|c|c|c|c|c|c|c|c|c|c|c|c|c|c|c|c|c|c|}
\hline \multirow[b]{2}{*}{$T \mathbf{a} \times \mathbf{a}$} & \multicolumn{29}{|c|}{ Locality } \\
\hline & 12 & 234 & $4 \sqrt{5}$ & 6 & 7 & $8 \sqrt{9}$ & & & 127 & & 61516 & & & & & & 22 & 23. & & & 262 & 272 & 282 & & & & 3233 & $344^{2}$ & \\
\hline Follicucullus scholasticus Ormiston \& Babcock & & & & & & & & & & & & & & & & & & & & & & & & & & & & $\bullet$ & \\
\hline Fo. monacanths Ishiga \& Imoto & e & & & & & & e & & - & - & 1.te & - & & & & & & & & & & & - & & & & & & \\
\hline Fo. Sp. A & 5 & 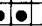 & & & & & $\bullet$ & & - & 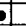 & To: & - & & & & & & & & & & $\cdot 0$ & $\bullet$ & & & & & & \\
\hline Fo.sp. & & & - - & & & & & & & & & & - & & - & & & $\bullet$ & & & & & & & - & - & - & & \\
\hline Pseudoalbaillella sp.C of Ishiga et al.(1982 b) & & & & $\bullet$ & $\bullet$ & & & & & & & & & & & & 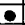 & & & & & & & & & & $\bullet$ & & \\
\hline Ps. Sp. aff. Ps. longicornis Ishiga 8 Imoto & & & e & a & $\bullet$ & - -0 & e & & & & & & & $\bullet$ & & $\bullet$ & $\bullet$ & & - & & & & 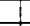 & & & & & & \\
\hline Ps. fusiformis Holdsworth \& Jones & & & & e & 0 & ef & & & & & & & & & & $\bullet$ & & & & & & & & & & & 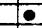 & & \\
\hline PS. Sp. D of ishiga et al. (1982 b) & & & - & & & & & & & & & & & & & & & & & & & & & & & & & & \\
\hline PS.SP.A & & & & $\bullet$ & - & & & & & & & & & & & 0 & - & & - & - & & & - & & & & - & & \\
\hline Ps.sp. & & & - & & & & $\bullet$ & & - & & 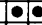 & 0 & & - & - & & & - & & - & & & & & & & & & - \\
\hline Albaillella asymmetrica Ishiga \& Imoto & & & & & & & & & & & & & & & 0 & & & & & & & & & of & & & & & \\
\hline A. sp. & & & & & & & & & & & & & & & $\bullet$ & & & & & & & & & & & & & & \\
\hline Ps. Sp. aff. Ps. scalprata Holdsworth \& Jones & & & & & & & & & & & & & & & & & & & & & - & & & & & & & & \\
\hline & sec & ctic & on & $Y$ & $f$ & & & & 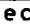 & & on & & & G & ; & C & & & & & & & & & & & & & \\
\hline
\end{tabular}

Stratigraphic distribution of radiolarians from locs. 1 to 9 and 10 to 22 are shown in sections YGB and YGC of Fig. 7, respectively.

\section{Explanation of Plate 7}

Fig. 1. Photomicrograph of chert crowded with siliceous sponge spicules. The matrix is red pigmented. Plane light. Perpendicular to the bedding surface. Scale bar $=1 \mathrm{~mm}$. Loc. $\mathrm{F}$ in Text-Fig. 2.

Fig. 2. Scanning electron micrograph of spicular chert etched by HF consisting dominantly of monactines with small amounts of triactines and tetractines. Parallel with the bedding surface. Scale bar $=100 \mu \mathrm{m}$. Loc. E in Text-Fig. 2.

Fig. 3. Siliceous lime-wackestone.

Note that crinoid oscicles are most abundant, and large siliceous sponge spicules are also present. Plane light. Scale bar $=1 \mathrm{~mm}$. Sampled from the siliceous limestone within a limestone lens shown in Text-Fig. 6. Loc. E.

Fig. 4. Siliceous lime-mudstone or biomicrite.

Tiny spicules are disseminated within the cloudy matrix comprising aggregate of microcrystalline calcite and quartz. The same locality as that of Pl. 7, Fig. 3. 

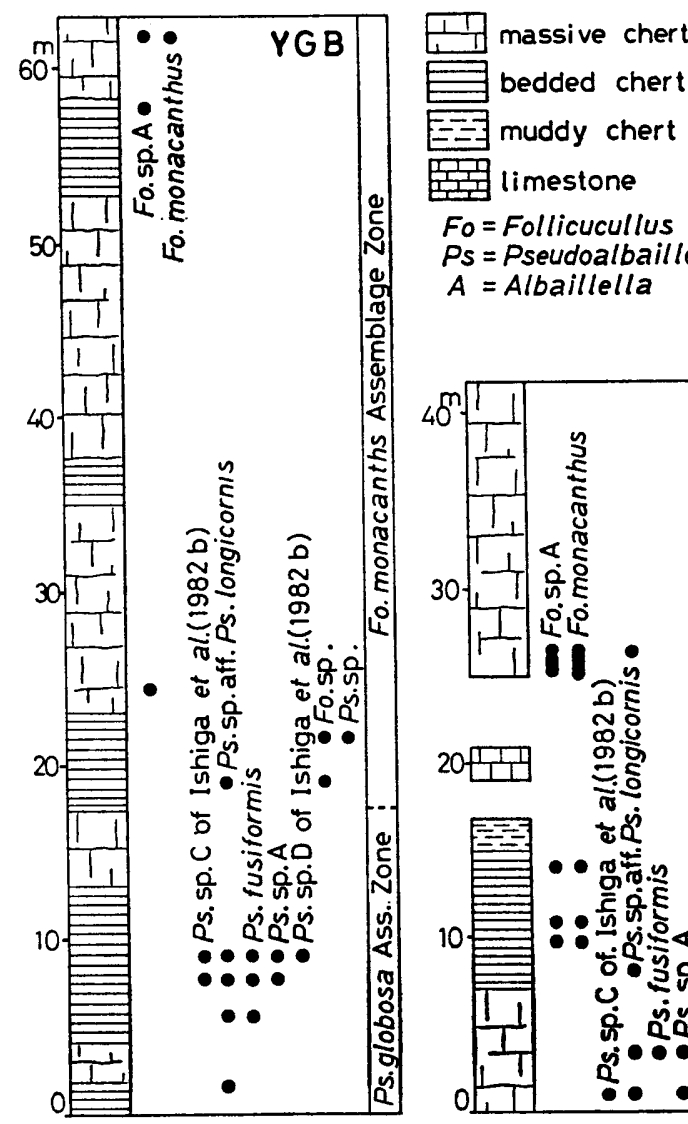

$P_{S}=$ Pseudoalbaillella

$A=$ Albaillella

Fig. 7. Stratigraphic distribution of radiolarian fossils along the selected sections. The section YGB (left) includes fossil localities numbered 1 to 9 in Fig. 2, and the section YGC (right) includes localities 10 to 22 .

\section{Explanation of Plate 8}

Fig. 1. Pseudoalbaillella sp. aff. Ps. scalprata Holdsworth \& Jones, loc. 26.

Fig. 2. Albaillella sp. cf. A. asymmetrica IshigA \& Iмото, loc. 29.

Fig. 3. Albaillella sp. loc. 20.

Fig. 4. Pseudoalbaillella sp. C of IsHigA et al. (1982b), loc. 7.

Figs. 5, 6. Pseudoalbaillella sp. aff. Ps. longicornis IshigA \& Imoto, locs. 6 and 8 , respectively.

Fig. 7. Pseudoalbaillella fusiformis HoldsworTh \& Jones, loc. 7.

Figs. 8-10. Pseudoalbaillella sp. A, locs. 7, 7, and 6, respectively.

Fig. 11. Pseudoalbacillella sp. D of IsHIGA et al. (1982b), loc. 6.

Figs. 12, 13. Follicucullus sp. A, loc. 17.

Fig. 14. Follicucullus monacanthus IshigA \& Iмото, loc. 28.

Fig. 15. Follicucullus scholasticus ORMISTON \& BABCOCK, loc. 34.

Scale bars $=100 \mu \mathrm{m}$ 


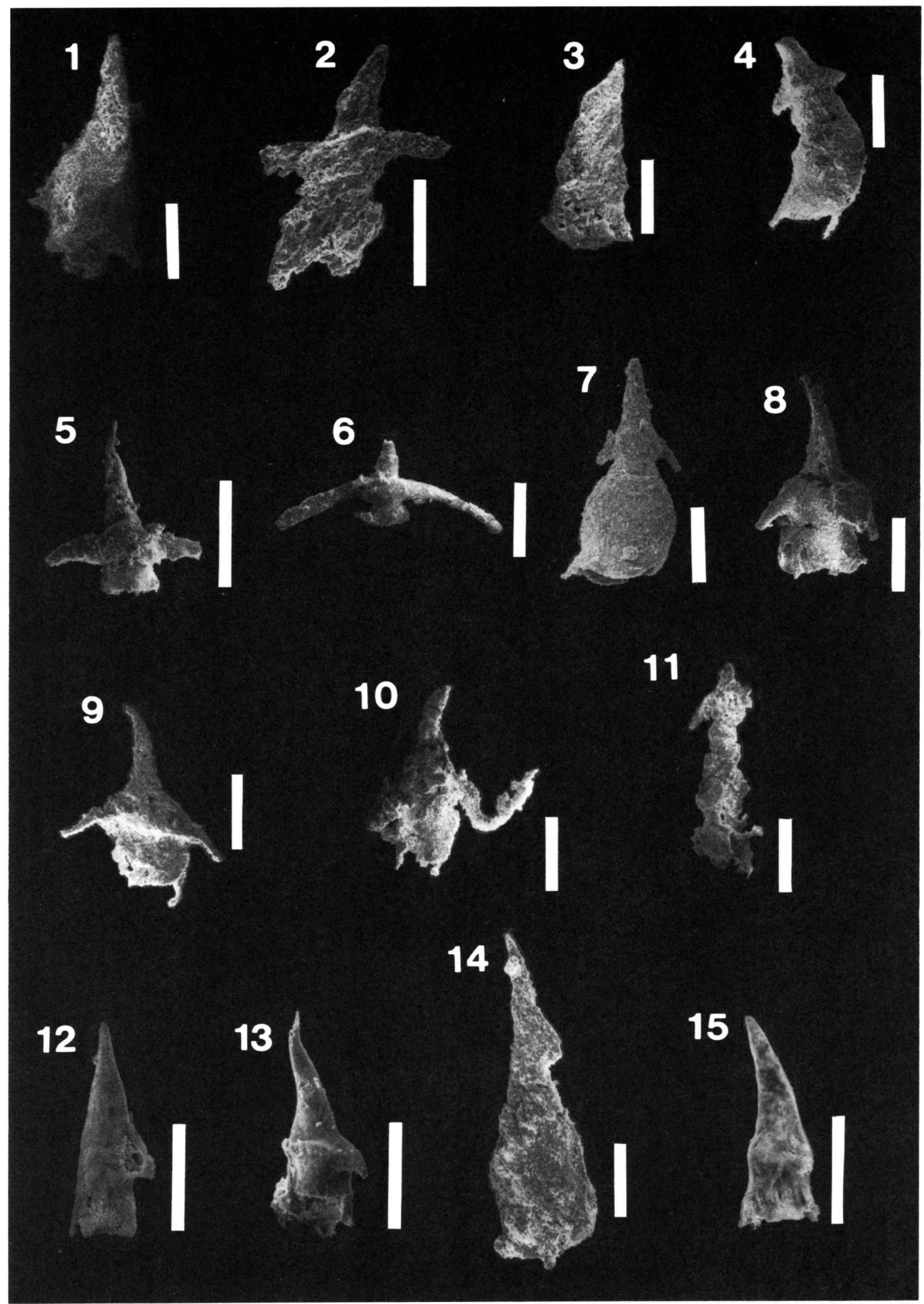

T. UCHIYAma et al.: Cherts around Akiyoshi 
in the Tamba district, central Japan. They are the Pseudoalbaillella lomentaria Assemblage zone, Albaillella sp. D Ass. zone, Ps. globosa Ass. zone, Follicucullus monacanthus Ass. zone, and Fo. scholasticus Ass. zone. Characteristic species of each assemblage zone are shown in P1. 8. The stratigraphic distribution of these assemblage zones were confirmed in two selected, thick sections of cherts (Fig. 7). Results of our radiolarian paleontological investigation proved that the minimum age of the cherts is coeval to the uppermost part of the Akiyoshi Limestone Group; late Middle Permian.

Datable fusulinacean fossils, on the other hand, have been reported from the limestone lenses within cherts at several localities in the area (ToRIYAMA, 1954; KaWANo et al., 1963; FUJII, 1972; KANMERA and Nishr, 1983; KANMERA, 1983). These fusulinacean fossils belong to the Eostafella zone, Pseudofusulina zone, and Neoschwagerina zone. Based on inferred contemporaneity of limestone lenses and cherts, and on the occurrence of the Early Carboniferous fusulinaceans from the limestone lenses at the lowest part of the chert sequence, the age of cherts could date back to Early Carboniferous. All lines of recently and previously reported paleontological evidence suggest that the cherts range in age from Early Carboniferous to late Middle Permian, being coeval to the whole thickness of the Akiyoshi Limestone Group.

\section{Depositional Setting of Cherts}

The cherts of the area are characterized by abundance of siliceous sponge spicules instead of radiolarian shells, association of volcaniclastic rocks at the base and admixture of volcanic detritus, and occurrence of displaced limestones. These properties signify a depositional environment different from that of radiolarian cherts, the most typical and common deep-water sediments in orogenic belts on land. Cherts of the same lithology and rock assemblages are widely distributed on the north and northwest sides of the Akiyoshi Limestone Plateau (KANMERA and NISHI, 1983; KANMERA, 1983) except for the area covered by the Cretaceous volcanic rocks on the east. All these cherts are coeval with the Early Carboniferous to late Middle Permian Akiyoshi Limestone Group of shallow-water environment origin. The Akiyoshi Limestone Group lies on a basic volcanic pedestal and can be referred to as an isolated oceanic seamount (KANMERA and NISHI, 1983; KANMERA, 1983). Throughout the sequence of cherts and underlying volcaniclastic rocks, and the Akiyoshi Limestone Group including the volcanic basement no terrigenous clastic layers are contained.

All lines of geological, sedimentological, and paleontological evidence permit the following interpretation on the origin and depositional environment of the cherts. First, the cherts are of biogenic origin, virtually consisting of siliceous sponge spicules, and the microcrystalline quartz cement was derived mainly from dissolution of sponge spicules through diagenetic processes. Second, the sponge spicule-rich sediments, hence spicular cherts, accumulated most likely on the flank and foot of a seamount capped by a reef complex of the Akiyoshi Limestone Group, and on the oceanic basin around the seamount as 


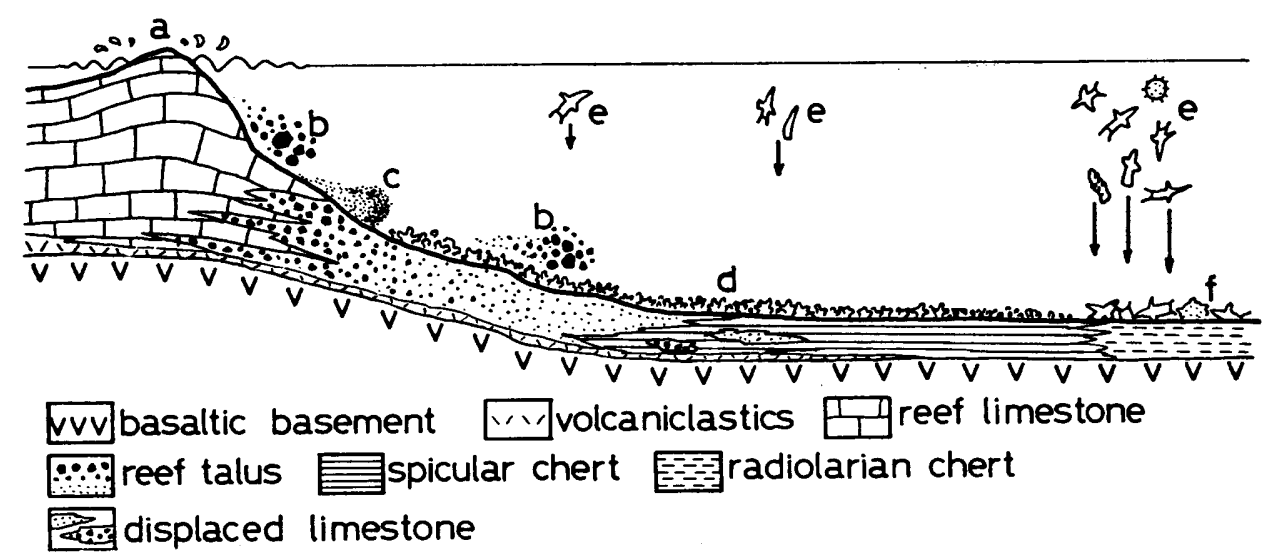

Fig. 8. A Model for depositional setting of spicular cherts around the Akiyoshi Limestone Group.

a. reef edge; b. debris fllow of shallow-water carbonates; c. calciturbidite;

d. siliceous sponges and their remains deposited in situ; e. radiolarians;

f. radiolaria-rich siliceous sediment.

suggested by KANMERA and NISHI (1983). The model illustrated on Fig. 8 for depositional environment would most properly explain the occurrence of the limestone lenses and the admixture of volcanic detritus in the lower part of the chert sequence; the unconsolidated, shallow-water carbonate sediments, as well as volcaniclastic sediments, could have been displaced as probable debris flow into much deeper depositional sites where siliceous sponges were flourished.

\section{Tectonic Implication of Cherts}

Before discussing tectonic implication of the cherts, the age of the terrigenous clastic rocks juxtaposed with the cherts and the Akiyoshi Limestone Group should be mentioned. Early and late Middle Permian fusulinacean fossils have been reported from the sandstones of the area (FUJII, 1972). However, the precise age of the sandstones can not be indicated by these fusulinacean fossils, for they occur as detrital, reworked particles within sandstones. These fusulinaceans have evidently derived from the Akiyoshi Limestone Group. Occurrence of Lepidolina multiseptata shiraiwensis of late Middle Permian age indicates that the depositional age of the sandstones is younger than that of the Akiyoshi Limestone Group, the top of which belongs to the Lepidolina multiseptata shiraiwensis zone (TORIYAMA, 1954). The mudstones of the area have not been dated by any fossils. However, to be mentioned is that the mudstones of the area west of the Akiyoshi Limestone Plateau yield late Middle Permian radiolarian fossils (Follicucullus monacanthus and Fo. schilasticus; Surzu, $1985 \mathrm{MS}$ ) and that they contain many lenticular bodies of limestone-breccia in some stratigraphic levels. The breccias consist of angular clasts of limestones of various sizes up to a few meters across and of varying ages ranging from Middle Carboniferous to late Middle Permian. They are all of exogenetic origin to the mudstones in which they are contained, and the fusulinacean and other 
fossils occurring from the limestone clasts clearly indicate their derivation from the Akiyoshi Limestone Group by its large collapse (KANMERA and NiSHI, 1983; KANMERA, 1983). The mudstones which yield the late Middle Permian radiolarians and which contain limestone-breccias of the same nature as those mentioned above are also distributed in the northwestern corner of the mapped area and underlie the thick-bedded sandstones containinig detrital fusulinacean fragments mentioned above. To sum up the above description, the terrigenous clastic rocks of the area range in age from late Middle Permian to probably Late Permian, and at least a part of the mudstones is equivalent in age to the top of the Akiyoshi Limestone Group and that of the cherts.

Based on lithologic affiliation and age, we recognized at least two juxtaposed tectonostratigraphic units. One is the Early Carboniferous to late Middle Permian unit of open-ocean setting that lay beyond reach of any terrigenous detritus from a continent, that is, an isolated oceanic reef-complex with a basaltic seamount pedestal and a volcaniclastics and overlying spicular chert sequence accumulated on the lower flank of the seamount and on the surrounding ocean floor. The other is the late Middle Permian terrigenous clastic unit probably of continental margin setting. It is evident from the aforementioned lithostratigraphy and rock assemblages that these two units formed in completely different environments and in largely different ages, although only the top part of the former and the lower part of the latter are equivalent in age to each other.

Within the Inner Zone of Southwest Japan, the greenstone-limestone sequences biostratigraphically and also lithologically equivalent to the Akiyoshi Limestone Group are aligned with a trend of ENE-WSW in the Taishaku, Koyama, Atetsu, and Omi districts (Fig. 9). Although the ages and the relation between the cherts and terrigenous clastic rocks in those areas have not been sufficiently determined except for findings of the Middle Permian radiolarians from

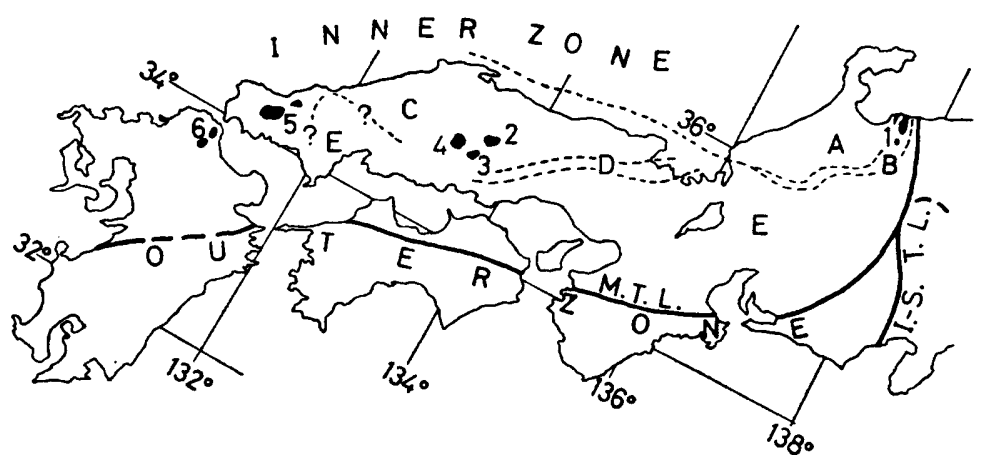

Fig. 9. Map illustrating the approximate distribution of the greenstonelimestone assemblages coeval to the Akiyoshi Limestone Group within the Inner Zone of Southwest Japan.

1. Omi; 2. Atetsu; 3. Koyama; 4. Taishaku; 5. Akiyoshi; 6. Hirao-dai and Funaoyama. A. Hida metamorphic belt; B. Hida marginal belt; C. Sangun belt; D. Maizuru belt; E. Tamba belt. M.T.L., Median Tectonic Line; I.-S.T.L., Itoigawa-Shizuoka Tectonic Line. 
cherts and mudstones at a few sites in the Taishaku district (IsozAKI, 1983), analogous tectonostratigraphic status can be also expected in those districts, because the Paleozoic rocks of those districts are very similar in overall distribution and lithologies to those of the Akiyoshi district.

Juxtaposition of two tectonostratigraphic units, as defined in the Akiyoshi district, is interpreted most likely as results of collision of seamount capped by the reef complex and accompanied by the coeval spicular cherts, and by their accretion toward the inner wall of a trench, which was being filled by terrigenous clastic sediments, resulting in chaotic mixing of oceanic and terrigenous rocks. Nature, timing and geologic setting of the collision and accretion has not been established. However, it is evident that these tectonic events have finished before deposition of the Late Triassic molasse sediments. Hence, the two tectonostratigraphic units are recognized as forming an allochthonous terrane accreted during Late Permian to Early Triassic times.

\section{Summary and Conclusions}

With regard to cherts and terrigenous clastic rocks intricately juxtaposed with each other in the area southerly adjacent to the late Early Carboniferous to late Middle Permian Akiyoshi Limestone Group, the following summary can be specified.

(1) Cherts, about $100 \mathrm{~m}$ thick, are succeeded from a 20-m-thick volcaniclastic unit with transitional beds consisting of interbedded volcaniclastic claystone and chert. This sequence entirely lacks terrigenous clastic layers.

(2) Most of cherts are rich in siliceous sponge spicules, thereby named spicular chert.

(3) In the upper half of the chert sequence five radiolarian assemblage zones which indicate middle Lower Permian to upper Middle Permian were discriminated.

(4) Limestone lenses occurring at several levels of the volcaniclastics-chert sequence are of skeletal debris flow origin derived from the Akiyoshi carbonate build-up. They are contemporaneous with the enclosing beds, and those in the lowest part indicate late Early Carboniferous in age. Hence, the volcaniclastics-chert sequence is deduced to be coeval with the almost whole sequence of the Akiyoshi Limestone Group.

(5) Terrigenous clastic rocks range in age from late Middle Permian to probably Late Permian. Therefore they are quivalent in age to the top of the Akiyoshi Limestone Group and the volcaniclastics-chert sequence.

(6) Although the terrigenous clastic rocks and the volcaniclastics-chert sequence are mostly in thrust or fault or shear surface contact to each other, some slabs and blocks of cherts retain adherent contact with uneven surfaces discordant to the enclosing terrigenous clastic rocks. This relation suggests that the juxtaposition of both rocks was primarily taken place while the terrigenous clastic rocks were still unconsolidated.

Thus, a couple of tectonostratigraphic units completely different lithologies are arranged in the Akiyoshi district: One is of open-ocean setting far re- 
moved from influx of terrigenous detritus, namely the late Early Carboniferous to late Middle Permian Akiyoshi Limestone Group consisting of a thick reef complex capped a basaltic pedestal, thereby interpreted as an oceanic seamount, and coeval volcaniclastics-chert sequence accumulated on the flank and foot of the seamount and on the surrounding ocean floor. The other is the late Middle Permian to probably Late Permian terrigenous clastic rocks, which are inferred to be continental margin deposits. The juxtaposition of these two units can be best explained by accretion tectonics discussed by KANMERA and NISHI (1983).

\section{Acknowledgements}

We express our gratitude to Assoc. Professor N. Imoto (Kyoto University of Education) and Mr. H. IshigA (Osaka City University) for their valuable suggestions on the Permian radiolarians and their biostratigraphy. We are also grateful to Dr. M. OTA (Museum of Natural History, Kitakyushu City) and Mr. T. Haikawa (Akiyoshi-dai Museum of Natural History), who kindly provided facilities to our field survey. Our research was financially supported by Grant-in-Aid for Fundamental Scientific Research from the Ministry of Education of Japan: No. 57540448, K. KANMERA; No. 57740441, H. SANo; No. 57340047, S. Mizutani at Nagoya University.

\section{References}

FujII, A. (1972): Ota Formation of the Yamaguchi Group in the Akiyoshi district. J. Geol. Soc. Japan, 78, 309-321.

and Mrkami, T. (1970): Tsunemori Formation-its relation with the Akiyoshi limestone. Ibid., 76, 545-557.

Hase, A., Okimura, Y. and Yokoyama, T. (1974): The Upper Paleozoic formations in and around Taishaku-dai, Chugoku Massif, Southwest Japan; with special reference to the sedimentary facies of limestones. Geol. Rept. Hiroshima Univ., $19,1-39$.

HAShimoto, K. (1979): Bio- and litho-facies of the Akiyoshi Limestone Group in southern area of the Akiyoshi Plateau. Bull. Akiyoshi-dai Mus. Nat. Hist., 14, $1-26$.

Ishiga, H., Kiтo, T. and Iмото, N. (1982a): Permian radiolarian biostratigraphy. News of Osaka Micropaleontologists, Spec. Vol., 5, 17-26.

,-- , and $-(1982 \mathrm{~b}):$ Middle Permian radiolarian assemblages in the Tamba and adjacent area, Southwest Japan. Earth Sci. (Chikyu Kagaku), 36, $10-22$.

IsozAKI, Y. (1983) : Findings of Paleozoic radiolarians from the Nagato tectonic zone in Yamaguchi Prefecture and the Taishaku area in Hiroshima Prefecture. Proc. Nishinihon Branch, Geol. Soc. Japan, 79, 7-8.

KANMERA, K. (1983): A problem on sedimentation and tectonics of Upper Paleozoic rocks in Southwest Japan-Accretion of allochthonous sedimentary bodies-. In Shuto, T. et al. (eds.), Geologic development of the Kyushu Island. Spec. Pub. Nishinihon Branch, Geol. Soc. Japan, 67-76.

and Nishi, H. (1983): Accreted oceanic reef complex in Southwest Japan. In Hashimoto, M. and Uyeda, S. (eds.), Accretion tectonics in the Circum-Pacific Regions. Terra Sci. Pub. Co., Tokyo, 195-206.

KawaI, M. (1963): On the deformation of the Mesozoic and Paleozoic systems in the 
Mine district, Yamaguchi Prefecture, Japan. Bull. Geol. Surv. Japan, 14, 701-723.

Kawano, M., Takahashi, E., Ishikawa, H., Matsugaki, S. and Harada, S. (1963): Ota Group-on the geologic structure and age. Bull. Akiyoshi-dai Mus. Nat. Hist., 2, 78-86.

Mikamr, T. (1974): Geological study of the Beppu Formation: Earth, Human and Education, Prof. H. Kasumi, Memorial Volume, 165-173.

Murata, M. (1961): On the geological structure of the Akiyoshi Plateau. Tohoku Univ., Inst. Geol. Paleont., Contrib., 53, 1-46.

NAGAI, K. (1978): Litho- and bio-facies of reef limestones in the Ryugoho area of the Akiyoshi Limestone Plateau. Bull. Akiyoshi-dai Mus. Nat. Hist., 13, 15-34.

OтA, M. (1968): The Akiyoshi Limestone Group: A geosynclinal organic reef complex. Ibid., 5, 1-44.

(1977) : Geological studies of Akiyoshi. Pt. 1, General geology of the Akiyoshi Limestone Group. Ibid., 12, 1-33.

Ozawa, Y. (1923): Stratigraphical study on the so-called Upper Chichibu Paleozoic system including the Akiyoshi Limestone. J. Geol. Soc. Japan, 30, 222-243.

(1925) : Paleontological and stratigraphical studies on the Permo-Carboniferous limestone of Nagato. Pt. 2, Paleontology. J. Coll. Sci. Tokyo Imp. Univ., 45, 1-90.

Suizu, M. (1985 MS): Geological study on the Tsunemori Formation in the western part of Akiyoshi Plateau. Master thesis of Division of Science, Kyushu Univ.

ToriYama, R. (1954a) : Geology of Akiyoshi, Pt. I. Stratigraphy of the Akiyoshi Limestone Group. Mem. Fac. Sci., Kyushu Univ., Ser. D, 4, 39-97.

(1954b) : Geology of Akiyoshi, Pt. II. Stratigraphy of noncalcareous groups developed around the Akiyoshi Limestone Group. Ibid., 5, 1-46. 